Review

\title{
Visible Light-Activated PhotoCORMs
}

\author{
Emmanuel Kottelat and Fabio Zobi * \\ Department of Chemistry, University of Fribourg, Chemin du Musée 9, CH-1700 Fribourg, Switzerland; \\ emmanuel.kottelat@unifr.ch \\ * Correspondence: fabio.zobi@unifr.ch; Tel.: +41-044-635-6802 \\ Academic Editor: Lígia M. Saraiva
}

Received: 14 March 2017; Accepted: 10 April 2017; Published: 13 April 2017

\begin{abstract}
Despite its well-known toxicity, carbon monoxide (CO) is now recognized as a potential therapeutic agent. Its inherent toxicity, however, has limited clinical applications because uncontrolled inhalation of the gas leads to severe systemic derangements in higher organisms. In order to obviate life-threatening effects and administer the gas by bypassing the respiratory system, $\mathrm{CO}$ releasing molecules (CORMs) have emerged in the last decades as a plausible alternative to deliver controlled quantities of $\mathrm{CO}$ in cellular systems and tissues. As stable, solid-storage forms of $\mathrm{CO}, \mathrm{CORMs}$ can be used to deliver the gas following activation by a stimulus. Light-activated CORMs, known as photoCORMs, are one such example. This class of molecules is particularly attractive because, for possible applications of CORMs, temporal and spatial control of CO delivery is highly desirable. However, systems triggered by visible light are rare. Most currently known photoCORMs are activated with UV light, but red light or even infrared photo-activation is required to ensure that structures deeper inside the body can be reached while minimizing photo-damage to healthy tissue. Thus, one of the most challenging chemical goals in the preparation of new photoCORMs is the reduction of radiation energy required for their activation, together with strategies to modulate the solubility, stability and nontoxicity of the organic or organometallic scaffolds. In this contribution, we review the latest advances in visible light-activated photoCORMs, and the first promising studies on near-infrared light activation of the same.
\end{abstract}

Keywords: photoCORMs; visible light; manganese

\section{Introduction}

Carbon monoxide (CO) has been known for a long time as a dangerous gas to mammals [1]. Indeed, due to its toxicity, colorless, odorless and tasteless nature, the gas is commonly referred to as "the silent killer". Carbon monoxide toxicity partially originates from the high affinity of the molecule for the iron of hemoglobin, with which it strongly interacts, thereby reducing the protein's ability to shuttle and transfer oxygen into tissues. However, it has also been demonstrated that hemoglobin acts as detoxifying protein and that it is rather the small amount of unbound $\mathrm{CO}$ that escapes it that is likely responsible for the main toxicity of the gas [2].

Despite its toxicity $\mathrm{CO}$, is produced endogenously in mammals by the Heme Oxygenase family of enzymes during heme catabolism. Studies on its role in mammals have revealed that CO plays a fundamental part as a gaseous signaling neurotransmitter, together with nitric oxide (NO) and dihydrogen sulfide $\left(\mathrm{H}_{2} \mathrm{~S}\right)$ [3]. Lack of endogenous $\mathrm{CO}$ production leads to systemic function disorders, including diabetes [4], inflammation [5-8], or tissue cellular apoptosis [4]. The discovery of the unexpected beneficial role of $\mathrm{CO}$ has led, on one hand, to its evaluation as a therapeutic agent in clinics and hospitals and, on the other hand, to an increasing interest in the chemistry of $\mathrm{CO}$. The former has most certainly fueled the latter as mounting biological and medicinal evidence indicates that $\mathrm{CO}$ can 
prevent or alleviate a variety of diseases, including, e.g., cardiovascular inflammation $[4,9,10]$, hepatic ischemia [11], cell proliferation [4] or have antiatherogenic [12] or cytoprotective effects [4,13], inter alia.

In order to exert its therapeutic effects, a proper amount of $\mathrm{CO}$ must be delivered in a controlled manner to avoid tissue hypoxia and severe toxic side effects. In its gaseous form, however, the molecule is difficult to handle and to administer in a precise concentration at a specific location within the organism. As a way to deliver the gas by bypassing the respiratory system, $\mathrm{CO}$ releasing molecules (CORMs) have emerged as an important research area, bridging disciplines ranging from organometallic and organic chemistry to pharmacology and medicine. The rising interests in these molecules are due to the fact that they, in principle, allow for the controlled and targeted delivery of the gas into wounded or injured tissues [14-18], depending on the nature and the specificity of the CORM used. To date, most CORMs are transition metal complexes bearing at least one carbonyl ligand. It is this ligand that once released from the molecule with a defined stimulus, acts as the endogenously generated $\mathrm{CO}$.

The majority of CORMs release CO thermodynamically, i.e., spontaneously by dissolution in the aqueous media $[19,20]$. The rate of CO delivery can be calculated kinetically by spectrophotometry or infrared analysis and can be modulated by modification of the ancillary ligands of the releasing complex [21,22]. Nevertheless, in the case of spontaneous CO liberation, the starting time of action can be difficult to control. Thus, a stimulus that can activate CORMs at a precise moment would be preferred. Enzyme-triggered release [23-26] or electromagnetic heating [27] are some of the ways used to initiate $\mathrm{CO}$ release. However, the most commonly employed stimulus for CORM activation is light. Several transition metal carbonyl complexes are known to be photosensitive, and they have been naturally studied to this end. Indeed, the number of publications on photoCORMs has increased exponentially in the last decade $[28,29]$. Early studies in this area resulted in promising compounds that were activated by UV light irradiation [30-34]. Unfortunately, the shortest wavelengths have poor penetration and are potentially harmful to healthy tissues. Thus, research in the area has also moved towards the discovery and preparation of photoCORMs that can be activated with radiations of longer wavelengths. These efforts have resulted in systems showing controlled CO release with red light activation and, in some instances, with radiations approaching the boundaries of near infrared excitation [21,35].

These systems are the subject of this brief review. Specifically, we have limited our contribution to papers that have appeared since 2010 and in particular, to photoCORMs activated with light of a wavelength $>450 \mathrm{~nm}$. However, when necessary for our discussion, we allowed for certain flexibility to these stringent selection criteria. In any case, this review is not comprehensive of all contributions in the CORM field in the mentioned timeframe and for a more wide-ranging view of CORMs and photoCORMs, the reader may refer to other reviews $[2,4,14-18,36-40]$. Before introducing the latest advances in visible and near-infrared activated photoCORMs, and in order to guide readers unfamiliar with the subject matter, we will begin with a brief historical overview of photoCORMs.

\section{PhotoCORMs: Identification and Design}

The term photoCORM was introduced by Ford and coworkers, who examined the delivery of small gasotransmitters (nitric oxide and carbon monoxide) from transition metal complexes, notably a tungsten complex (1, Figure 1) showing CO release and water solubility [41]. Motterlini and co-workers reported the first biological use of light-induced CO release from chemical compounds, namely the pure metal carbonyl complexes $\mathrm{Fe}(\mathrm{CO})_{5}\left(2\right.$, Figure 1) and $\mathrm{Mn}_{2}(\mathrm{CO})_{10}$ (3, Figure 1) [19]. Due to poor aqueous solubility and toxicity, most notably for the Fe compound, the development of these CORMs was only possible by modifying the ancillary ligands around the metal center. Over the years the $f a c-\left\{\mathrm{Mn}(\mathrm{CO})_{3}\right\}^{+}$core became the prominent moiety in the advancement of photoCORMs. The first ligand used in such $f a c-\left\{\mathrm{Mn}(\mathrm{CO})_{3}\right\}^{+}$-based photoactivatable $\mathrm{CO}$ delivery systems was the tridentate tris(pyrazolyl)methane published by Schatzschneider (4, Figure 1). The resulting photoCORM released 2 equivalents of CO per Mn unit [31,32]. 
<smiles></smiles>

1

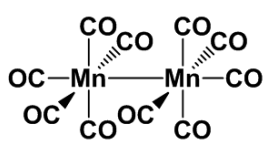

3<smiles></smiles>

2

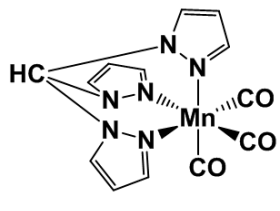

4

Figure 1. Early photoCORM structures.

Generally speaking, the mechanism of CO labilization and loss from transition metal carbonyl complexes is nowadays well understood. Due to the high $\pi$-accepting capability of the carbonyl ligand, $\mathrm{CO}$ induces a strong ligand field enhanced by synergistic $\mathrm{CO} \sigma$-donation to an empty metal $d$-orbital and $\pi$-backbonding from an occupied $d$-orbtital to the $\pi^{*}$ antibonding orbital of CO. Irradiation of the photoCORM with sufficient energy can promote excitation of $d$-orbital electrons increasing, on one hand, the formal oxidation state of the central metal ion and, consequently, reducing the synergistic $\mathrm{M}-\mathrm{CO} \sigma / \sigma$ interaction. The net result of irradiation is that of weakening the metal-carbonyl bond, thereby promoting $\mathrm{CO}$ release. This simplified picture is also useful for understanding photo-induced $\mathrm{CO}$ release ensuing from metal-to-ligand charge transfer (MLCT) processes where electrons are excited (i.e., transferred) from a metal $d$-orbital to the $\pi^{*}$ anti-bonding orbital of an ancillary ligand. This last process is one of the most prominent pathways leading to the photo-labialization of $\mathrm{CO}$ and examples of it will be discussed in more details in the ensuing sections.

The role of the ancillary ligands is decisive for tuning MLCT, the irradiation wavelength, the rate of $\mathrm{CO}$ loss and the toxicity of the photoproducts. In order to achieve visible light photoactivation, the energy gap of the orbital involved in electron transfer (e.g., HOMO-LUMO energy levels) needs to be as narrow as possible. Ancillary ligands with hyperconjugation and $\pi$-acceptors groups on the ligand frame are used for this purpose, along with $\pi$-donor atoms directly bound to the metal center [21]. Bromide and chloride anions are often the first choice of the latter type of ligands [22]. Tuning the wavelength of activation of photoCORMs is only one aspect to render the species possibly valuable for further medical applications. In principle, any photoCORM has to be biocompatible with animal systems to be further investigated. Thus, solubility in water, in biological media (phosphate buffer solution, PBS) or water $(\leq 0.5 \%)$ DMSO mixture, the non-toxicity of the CORM and the photoproducts, as well as their elimination from the organism, are all key requirements for a pharmaceutically useful photoCORM. Without light irradiation, stability in water and under aerobic conditions is also necessary for the tested compounds. For adequate use as therapeutic agents, only light irradiation must provide $\mathrm{CO}$ release and the decomposition into photoproducts.

An ideal photoCORM needs to release $\mathrm{CO}$ in a controlled manner and in correct amounts. At least one $\mathrm{CO}$ equivalent should be delivered per metal center. Thus, confirmation of the photoactivity of the $\mathrm{CO}$ releasing molecule is necessary. The most commonly used experiment to assess photo-CO release is the myoglobin assay, a spectrophotometric assay that allows monitoring the formation of carboxyMyoglobin (MbCO) [42]. Typically, a myoglobin solution of known concentration is prepared, and sodium dithionite is used to reduce ferric to ferrous iron in the heme of the metalloprotein before the addition of 1 (or more) equivalent(s) of the tested compound. If the latter is not soluble in pure water, a final percentage of $0.5 \%$ of DMSO is generally safe. Binding of CO to the ferrous heme (in this case referred to a deoxyMyoglobin, $\mathrm{dMb}$ ) is then monitored by $\mathrm{UV}$ analysis. If $\mathrm{CO}$ is indeed 
released from the photoCORM, the visible absorption band of $\mathrm{dMb}$ at $560 \mathrm{~nm}$ is progressively replaced by two bands at 540 and $579 \mathrm{~nm}$ (typical of $\mathrm{MbCO}$ ); the Soret band shows also a shift, from ca. 435 to $424 \mathrm{~nm}$ [18]. While this assay has proven extremely valuable in the identification and screening of CORMs, it should be kept in mind that the same assay is not perfect. McLean, Mann and Poole have shown that in some instances, and depending on the type of CORM being evaluated, sodium dithionite can influence $\mathrm{CO}$ release and give rise to artefacts [43]. Alternative experiments for $\mathrm{CO}$ release assessment have been developed; these include gas chromatography [41], portable CO sensors [44], IR [45] and fluorescence [46] spectroscopy.

\section{UV Light Photoactivated CORMs}

The conception of new photoactivatable $\mathrm{CO}$ releasing molecules, which are nontoxic, stable in physiological media and safe and efficient $\mathrm{CO}$ deliverers upon visible light illumination, remains a challenge. To date, the vast majority of organic and organometallic photoCORMs provide CO only upon UV light irradiation [47-52]. The tris(pyrazolyl)methane photoCORM characterized by Schatzschneider (4, Figure 1$)$ and co-workers is a typical example. This $f a c-\left\{\mathrm{Mn}(\mathrm{CO})_{3}\right\}^{+}$-based complex is cationic in nature; it shows good water-solubility and anticancer activity [32] and could also be used as a tag in medical imaging applications due to the characteristic and intense IR bands of the carbonyl stretching frequencies [34]. Furthermore, the tripodal ligand could be used to tune the outer coordination sphere of the photoCORM without altering the photoactivity of the compound. Peptide functionality or binding to $\mathrm{SiO}_{2}$ surface were thus reported for similar compounds showing similar $\mathrm{CO}$ releasing properties [30].

Other examples of $f a c-\left\{\mathrm{Mn}(\mathrm{CO})_{3}\right\}^{+}$-based photoCORMs with tripodal ligands have also been reported. Berends and Kurz replaced a pyrazolyl ring by an acetate unit, thus conferring a neutral charge to the complex (5 and 6, Figure 2) [53]. They demonstrated a stepwise CO loss process and hypothesized the formation of intermediate photoproducts before the oxidation of the metal center and the formation of a Mn-O-Mn moiety. Moreover, this complex had better CO release capabilities than the tris-pyrazolyl CORM of Schatzschneider. Recently, the group of Kelebekli reported novel tricarbonyl Mn complexes bearing bipyridiyl and imidazole derivatives (7 and 8, Figure 2) [54,55]. This set of complexes showed effective cancer treatment and cytotoxic activity against breast cancer cells and the MCF-7 human cell line. Antioxidant capability and redox properties were also revealed, by scavenging 2,2-diphenyl-1-picrylhydrazyl, superoxide and nitroxyl radicals. Taken together, the results showed promising steps for the use of photoCORMs as drug templates for the treatment of breast cancer. Tinajero and coworkers reported an Mn-based photoactivated CORM which reduces growth and viability of Escherichia coli, only by light induction [56]. They demonstrated that $\mathrm{CO}$ binds to specific intracellular sites, namely, respiratory oxidases and a globin protein expressed in a particular strain, while the Mn metal center is not accumulated in the cells. This study is notably the first investigation of the antimicrobial activity of a photoCORM against a resistant pathogen. The understanding of the mechanisms of the CORM toxicity is in fact the key challenge for the increase in the use of such compounds as therapeutic agents.

As solubility and nontoxicity are amongst the required elements for a valuable therapeutic CORM, the use of various biocompatible scaffolds is displaying a marked increase in publications (vide infra). For example, Yang and coworkers synthesized and characterized sawhorse-shaped ruthenium complexes with diverse amino and carboxylic acid derivatives on the outer coordination sphere of the CORM [57]. Cell viability investigation of $\mathbf{1 0}$ (Figure 2) indicated the absence of toxicity with or without irradiation. While the compound was stable in the dark for hours, CO release was proven by the common myoglobin assay, making it a potential lead structure for further investigations.

Mascharak and coworkers reported recently an interesting use of photoCORMs as luminescent trackers [58]. The orange color assigned to the intact CORM (11, Figure 2) was used to successfully track the entry of the prodrug into the cancer cells, while the shift to deep blue fluorescence after $\mathrm{CO}$ loss was used for the assessment of the delivery in specific cellular sites. The utility of the theranostic 
photoCORM was proven in breast cancer cells with the help of flow cytometry and fluorescence microscopy, attesting the therapeutic potential of the compound.

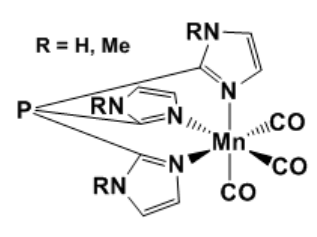

5

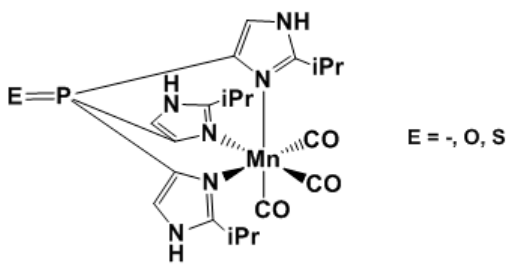

6

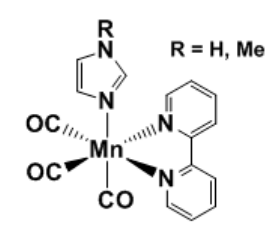

7

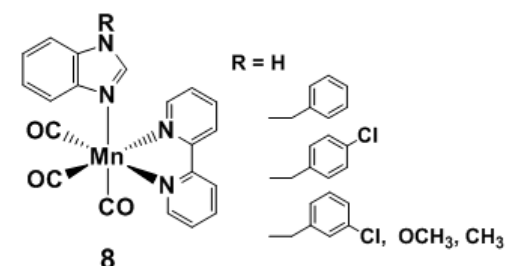

8

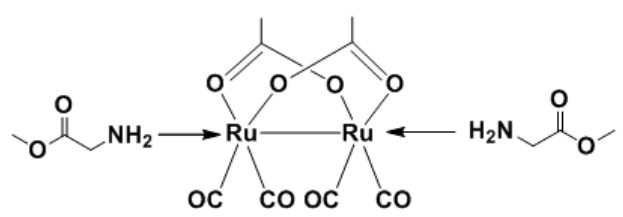

10

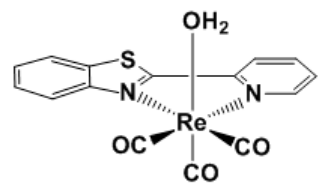

11

Figure 2. Selected examples of UV-activated photoCORMs.

\section{Visible Light and Near Infrared-Light (NIR) Photoactivated CORMs}

\subsection{Inorganic and Organometallic PhotoCORMs}

Westerhausen and co-workers reported in 2011 a dicarbonylbis(cysteamine)iron(II) complex (12, Figure 3), named CORM-S1 [59]. To our knowledge, this is the first photoCORM activated by visible light (i.e., $>450 \mathrm{~nm}$ ). Indeed, $470 \mathrm{~nm}$ light irradiation of 12 promotes constant $\mathrm{CO}$ release over several minutes, whereas exposition to broadband white light leads to rapid and complete CO liberation in a physiological medium. This property together with the high water solubility of the complex argues for its biocompatibility. The cysteamine ligand does not seem provide easy possibilities for further modifications of the inner- and outer-coordination sphere of the molecule, in order to finely tune the excitation wavelength needed for the CO liberation. Nonetheless, Motterlini and coworkers [60] did derivatize the corresponding ligand into cysteinate. More recently, Westerhausen [61] proposed the thiolato-bridged [ $\left.\left\{(\mathrm{OC})_{3} \mathrm{Mn}\right\}_{2}\left(\mu-\mathrm{SCH}_{2} \mathrm{CH}_{2} \mathrm{NH}_{3}\right)_{3}\right]$ dimer, obtained from the reaction of pentacarbonyl manganese with cysteamine (13, Figure 3). The complex was shown to be highly soluble in water, stable under anaerobic conditions and released CO when irradiated at $365 \mathrm{~nm}$ and $470 \mathrm{~nm}$. Although CO liberation was faster with UV-light, both irradiation wavelengths promoted delivery of the all six COs. Another interesting example of biocompatible photoCORM is the [FeFe]-hydrogenase derivative proposed by Fan and co-workers (14, Figure 3) [62]. The carboxylate groups on the side chain provide 
a polar water soluble complex, and COs are completely released by white light irradiation. Detailed investigations with a specific irradiation at $390 \mathrm{~nm}$ were also performed. Cell proliferation assay on MCF-10A epithelial cells indicates that the salt $\mathrm{Na}_{2}\left[\left(\mu-\mathrm{SCH}_{2} \mathrm{CH}_{2} \mathrm{COO}\right)-\mathrm{Fe}(\mathrm{CO})_{3}\right]_{2}$ (i.e., $\mathrm{Na}^{+}$salt of 14) is not cytotoxic.

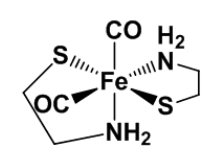

12

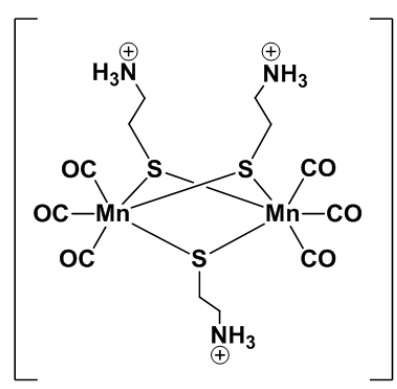

13
$2 \mathrm{Br}^{-}$

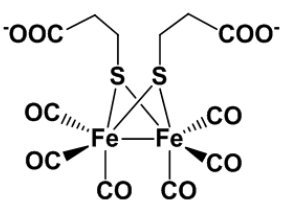

14

Figure 3. CORM-S1 (12) thiolato-bridged $\mathrm{Mn}(\mathrm{CO})_{3}$ based (13) and [FeFe]-hydrogenase based photoCORM (14).

Early in 2012, Mascharak reported the use of (2-pyridylmethyl)(2-quinolylmethyl)amine as tripodal based ligand (15, Figure 4$)$ for $f a c-\left\{\mathrm{Mn}(\mathrm{CO})_{3}\right\}^{+}$complexes [63]. This photoCORM was activated by visible light. Later that year, the same group reported the most prominent step towards visible light activation of photoCORMs, using highly conjugated Schiff bases as ligands for similar cores (16-18, Figure 4) [64]. Noticeable in the series were the $\left[\mathrm{MnBr}(\mathrm{CO})_{3}\right.$ qmtpm] (17, Figure 4) and $\left[\mathrm{MnBr}(\mathrm{CO})_{3} \mathrm{pmtpm}\right](\mathbf{1 8}$, Figure 5) complexes, which exhibit MLCT maximal absorbance at 535 and $500 \mathrm{~nm}$, respectively. As described above, the small energy transition could be explained by the combined effect of hyperconjugation of the bidentate ligand, the $\pi$-donor character of the bromo ancillary ligand and the electron donating nature of the-SMe group. These considerations led the same group to the design and synthesis of azobipyridine type complexes (19, Figure 4) reported in 2014 [65]. The complex with Mn as the metal center and bromide as the sixth ancillary ligand exhibits MLCT transition at $585 \mathrm{~nm}$, whereas the same complex with an Re center shows a MLCT band at $530 \mathrm{~nm}$. As this later compound also displays MLCT under visible light, one might have expected it to be the first $\mathrm{CO}$ releasing molecule with a $\mathrm{Re}^{\mathrm{I}}$ center. The myoglobin assay, however, does not indicate any $\mathrm{CO}$ delivery. DFT calculations performed to understand this discrepancy indicate that the spin-orbit coupling (prominent in heavy metals [66]) promotes intersystem ${ }^{1} \mathrm{MLCT}-{ }^{3} \mathrm{MLCT}$ crossing in the rhenium complex, thereby dissipating the excitation energy without inducing Re-CO bond rupture. As expected, both complexes with $\mathrm{PPh}_{3}$ as the ancillary ligand show low MLCT transition energy due to the high $\pi$-acceptor character of $\mathrm{PPh}_{3}$.

More recently, the group of Mascharak published visible light-induced $\mathrm{CO}$ release by a biocompatible tris-carbonyl Mn-based photoCORM showing good water-solubility [67]. Three $\alpha$-diimines ligand-based complexes were prepared (20-22, Figure 4) and one of them (21, Figure 4) demonstrated carbon monoxide delivery to myoglobin in PBS solution. In these complexes, one of the imine functions is not part of a conjugated rigid ring, leading to higher molar absorbance and faster $\mathrm{CO}$ release, compared to imines in a rigid $\alpha$-diimine ring system of bipyridine or phenanthroline type ligands [68]. In order to enhance the accumulation on the targeted specific site, cellular uptake, non-toxicity of byproducts and water-solubility of these CORMs, Mascharak and his group proposed ligand-appended adamantylamine derivatives [33,69]. Aminoadamantane-containing compounds are commercially available in the pharmaceutical market and are used for the treatment of ovarian carcinoma or human prostate and colon cancer [70,71]. Side effects of released adamantine-based ligands following photo-activation of CORMs and their cellular uptake were also studied in detail and indicated promising results [71]. Of the series of 
molecules, only complex 21 dissolved in pure aqueous media and physiological PBS conditions and remained stable for at least $24 \mathrm{~h}$ if kept in the dark. The three CORMs showed CO delivery upon illumination with light $\geq 450 \mathrm{~nm}$. The CO release rates increased according to the order $\mathbf{2 0}<\mathbf{2 1}<\mathbf{2 2}$ in $\mathrm{CH}_{2} \mathrm{Cl}_{2}$, and $\mathrm{UV}$ analysis indicated that 21 released 2 eq. of $\mathrm{CO}$ upon light irradiation under aerobic conditions in water. Furthermore, the photo-activation of $\mathbf{2 1}$ appears to be insensitive to dithionite or glutathione reductants.

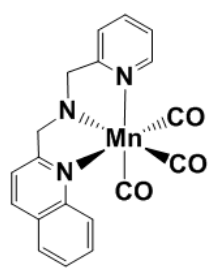

15

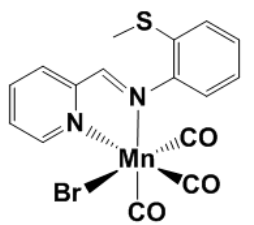

18

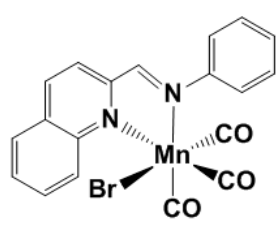

16

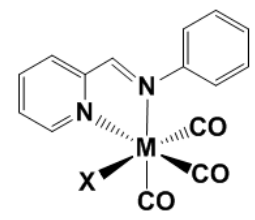

19

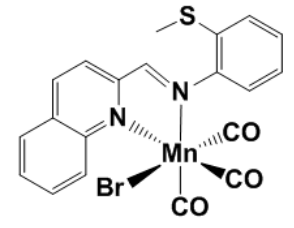

17

$\mathrm{X}=\mathrm{Br}, \mathrm{PPh}_{3}$

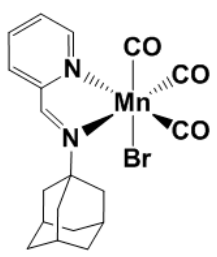

20

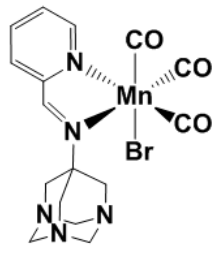

21

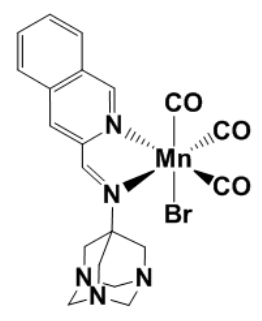

22

Figure 4. Selected structures of photoCORMs developped by Mascharak et al. [63-65,67].

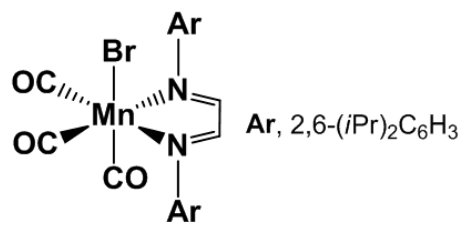

23

Figure 5. Structure of Bengali's photoCORM.

Since hyperconjugated diimines ligands coordinated to $f a c-\left\{\mathrm{Mn}(\mathrm{CO})_{3}\right\}^{+}$complexes permit photoCORM activation and liberation of carbon monoxide with visible light, the group of Bengali proposed compound 23 (Figure 5) [72]. The MLCT transition of this species was observed at $582 \mathrm{~nm}$, and $560 \mathrm{~nm}$ light irradiation provided rapid $\mathrm{CO}$ release by substitution of the carbonyl with a solvent molecule $\left(\mathrm{CH}_{3} \mathrm{CN}\right.$ or THF). DFT calculations on 23 and the corresponding diimine tetracarbonyl manganese cation indicate that the bulky steric environment around the carbonyl ligands is the predominant cause of the weakening of the metal-carbonyl bond interaction.

An approach to visible-light activated CORMs, which also took into consideration the toxicity of the ensuing photoproducts, was described by Mansour and Shehab, who reported the tazarotene (TZ) and metamizole $(\mathrm{MZ})\left[\mathrm{MnBr}(\mathrm{CO})_{3} \mathrm{TZ}\right]\left(\mathbf{2 4}\right.$, Figure 6) and [ $\left.\mathrm{MnBr}(\mathrm{CO})_{3} \mathrm{MZ}\right](\mathbf{2 5}$, Figure 6) species [73]. 
Both TZ and MZ are approved drugs in medical treatments [74,75], and following photo-CO release and dissociation from the $f a c-\left\{\mathrm{Mn}(\mathrm{CO})_{3}\right\}^{+}$core ensured no toxicity of the photoproducts. TZ interacts with the Mn center as a bidentate (N-pyridine- and $\mathrm{C} \equiv \mathrm{C}-$ ) ligand while $\mathrm{MZ}$ behaves as tridentate ligand. Although these photoCORMs (i.e., 24 and 25) demonstrated poor stability in DMSO, they are able to release $\mathrm{CO}$ upon exposure to blue light $(468 \mathrm{~nm})$. Under these conditions, complex 24 released 1 eq. of $\mathrm{CO}$ after $42 \mathrm{~min}$ of irradiation while 25 only 0.5 eq. after $70 \mathrm{~min}$. When 24 and 25 were irradiated at longer wavelengths $(535 \mathrm{~nm})$ and tested via the myoglobin $(\mathrm{Mb})$ assays, no evidence of $\mathrm{CO}$ loss or of $\mathrm{Mb}-\mathrm{CO}$ binding could be observed. The antimicrobial activity of $\mathrm{TZ}, \mathrm{MZ}$ and their corresponding CO releasing molecules $\mathbf{2 4}$ and $\mathbf{2 5}$ was also tested against two bacterial strains. Both TZ and MZ drugs are ineffective against Staphylococcus aureus and Escherichia coli, but the authors mentioned that 24, and to a lower extent 25, demonstrates higher antimicrobial effects. The authors suggested, therefore, that the coordination of the two drugs to the $f a c-\left\{\mathrm{Mn}(\mathrm{CO})_{3}\right\}^{+}$moiety results in an increased antibacterial effect.

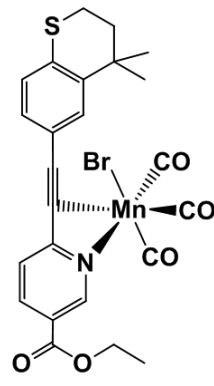

24

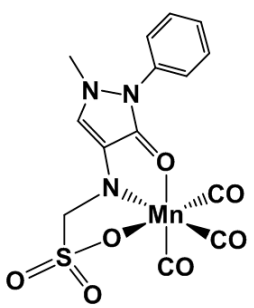

25

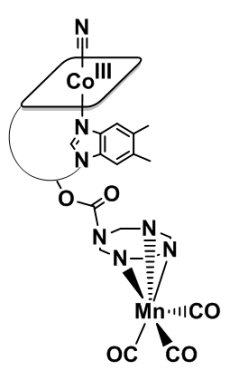

26

Figure 6. PhotoCORM structures of Mansour $(\mathbf{2 4}, \mathbf{2 5})$ and Zobi's B12-MnCORM (26).

A bio-compatible vitamin $\mathrm{B}_{12}$-conjugate bearing the same $f a c$ - $\left[\mathrm{Mn}(\mathrm{CO})_{3}\right]^{+}$core $(\mathbf{2 6}$, Figure 6) was the subject of a study published by our group in 2013. IR spectromicroscopy was used to characterize the intracellular uptake and reactivity of the photosensitive compound (in 3T3 fibroblasts), whose CO releasing properties could be triggered by illumination with visible light $(470 \mathrm{~nm})$. The intracellular reactivity of the compound, evaluated as a function of the release of the $\mathrm{CO}$ ligands following light exposure, was elucidated. The distribution of the complex could be described by IR mapping and, taking into consideration the role of cellular topography in the quantitative interpretation of the maps, a perinuclear distribution, in the nucleus and/or in its proximity, appeared to be the most likely interpretation of the images obtained. Intracellular photoinduced CO release of $\mathbf{2 6}$ prevents fibroblasts from dying under conditions of hypoxia and metabolic depletion, conditions that may occur in vivo during insufficient blood supply to oxygen-sensitive tissues such as the heart or brain.

\subsection{Organic PhotoCORMs}

An interesting novel feature of a class of photoCORMs bearing flavonato derivatives was demonstrated by Berreau and coworkers [76]. They reported two types of $\mathrm{Zn}$ (II) flavonolato complexes that exhibit red-shift energy absorbance and enhanced $\mathrm{CO}$ release compared to the free corresponding flavonols. These ligands (27-30, Figure 7) were known to deliver CO in organic or organic/water media when induced by visible light [77]. In this latter publication, the tuning on the phenyl moiety of the flavonol structures was demonstrated to be relevant for the red-shift of the absorption maximum of the free ligand. Whereas 27 exhibits an absorption centered at $409 \mathrm{~nm}$, the dialkylamine subunit on 28 shifted the same absorption band to $442 \mathrm{~nm}$. With both dialkylamine and thione present (30), the maximum was observed at $544 \mathrm{~nm}$. The characterization of the flavonolato complexes (31-34, Figure 7) indicated a spectral absorption band in the therapeutic window (>650 nm) and a solid-state $\mathrm{CO}$ release reactivity comparable to the activity seen in solution when irradiated with $546 \mathrm{~nm}$ light. The quantum yield was also significantly higher for the $\mathrm{Zn}$ compounds with respect 
to the neutral flavonols and reported organic photoCORMs [78,79]. A 1 eq. of CO per $\mathrm{Zn}$ unit is delivered from 31-34 when dissolved in pyridine. Similar to the free flavonols, the MLCT maximum of the corresponding complexes shifted gradually from $480 \mathrm{~nm}$ (for 31) to $600 \mathrm{~nm}$ (for 34), showing that the tunability of the ligand framework impacts the MLCT without influencing the amount of CO release. Furthermore, the bis-flavonato based complexes (35-38, Figure 7) demonstrated release of 2 eq. of CO per $\mathrm{Zn}(\mathrm{II})$. Surprisingly, 35 and 36 do exhibit also 2 eq. of CO release in the solid state, while 37 and 38 do not. The MLCT maximum of 35-38 was comparable to the corresponding 31-34 complexes. It should also be mentioned that $\mathrm{CO}$ release of both free ligands 27-30 and complexes 31-38 exhibit dioxygenase-type $\left(\mathrm{O}_{2}\right.$-dependent $) \mathrm{CO}$ release reactivity and the flavonato species are degraded by dioxygenase-type enzymes when $\mathrm{CO}$ is released, either by thermal reactivity [80] or enzyme catalysis [81]. Moreover, compound 35, when coated as a film on a flask, showed the delivery of CO in oxidative palladium-catalyzed carbonylation processes. A total of 1 eq. of $\mathrm{CO}$ was delivered after $24 \mathrm{~h}$ of irradiation of the evaluated solid film. Overall, these results suggest that flavonolato derivatives are adjustable molecules for the design of and development of both inorganic and organic photoCORMs, and these solid bis-flavonolato derivatives can be used in oxidative catalyzed alkoxycarbonylations as $\mathrm{CO}$ releasing agents. However, further studies on efficiency and applications of this novel feature need to be assessed.
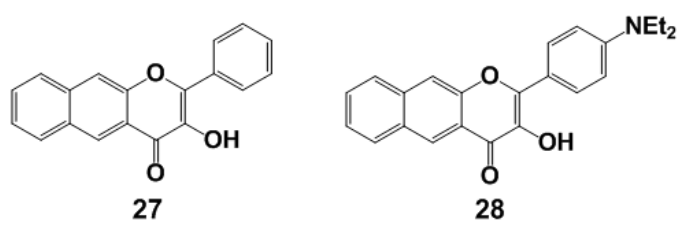

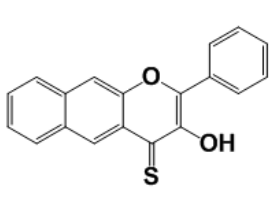

29

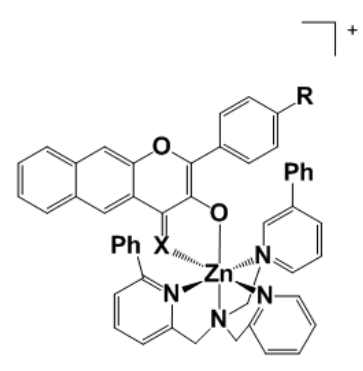

$$
\begin{aligned}
& \text { 31, X }=\mathrm{O}, \mathrm{R}=\mathrm{H} \\
& \text { 32, X }=\mathrm{O}, \mathrm{R}=\mathrm{NEt}_{2} \\
& \text { 33, X }=\mathrm{S}, \mathrm{R}=\mathrm{H} \\
& 34, \mathrm{X}=\mathrm{S}, \mathrm{R}=\mathrm{NEt}_{2}
\end{aligned}
$$<smiles>CCN(CC)c1ccc(-c2oc3cc4ccccc4cc3c(=O)c2O)cc1</smiles>

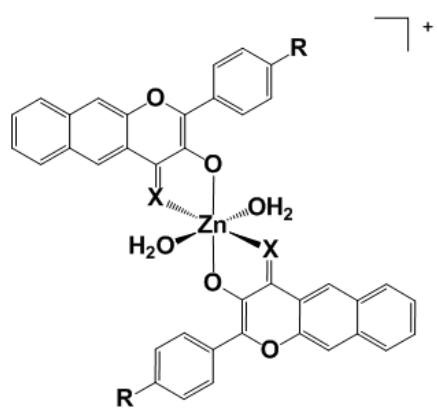

$$
\begin{aligned}
& 35, X=O, R=H \\
& 36, X=O, R=N t_{2} \\
& 37, X=S, R=H \\
& 38, X=S, R=\mathrm{NEt}_{2}
\end{aligned}
$$

Figure 7. Structures of flavonols 27-30 (top) and their Zn complexes 31-38.

The main advance towards visible light induction of organic photoCORMs was accomplished by Klán and coworkers [79]. Two boron dipyrromethene (BODIPY) derivatives were used as non-metallic CORMs. BODIPY compounds are widely known as strong chromophores. The CO releasing properties of molecules 39 and 40 (Figure 8) their biocompatilibity and toxicity were evaluated by Klán at several irradiation wavelengths (350-730 nm). Molecule 39 exhibits photochemical decomposition with $500 \mathrm{~nm}$ light irradiation. Compound $\mathbf{4 0}$ was designed with an extended $\pi$-system in order to decrease the LUMO level energy by $\pi$ delocalization. Under aerobic condition in PBS, 40 showed 
CO release upon irradiation at 358 and $652 \mathrm{~nm}$ (both absorption maxima of the molecule) and also at $732 \mathrm{~nm}$, at the absorption tail. However, under aerobic conditions the quantum yield of 39-40 drops to ca. $45 \%$ of the maximum. Thus, in opposition to the flavonol compounds, the BODIPY derivatives operate best in anaerobic environments. In in vivo experiments, hairless mice were separated in three groups, (i) without any treatment; (ii) with intraperitoneal application of $\mathbf{4 0}$ left in the dark; (iii) with intraperitoneal application of $\mathbf{4 0}$ followed by irradiation for $4 \mathrm{~h}$ with white light. This last group exhibited accumulation of carboxyhaemoglobin in blood, and high CO levels in kidney and hepatic tissues. Additionally, an in vitro blood sample containing $\mathbf{4 0}$ was irradiated and there also, $\mathrm{CO}$ could be easily detected. Furthermore, irradiation of a long-lasting sample was evaluated and revealed that $\mathrm{CO}$ release stopped when the illumination was suspended, granting control over the $\mathrm{CO}$ delivery. Finally, the mechanism of $\mathrm{CO}$ loss was assessed as being provided by a photoinduced electron transfer (PET) from the carboxylate to the BODIPY moiety, leading to an intersystem crossing from an excited singlet state to the triplet state. Finally, these compounds showed no in vivo toxicity in mice making this class of near-infrared light activated photoCORMs a major advance towards longer wavelength induction. However, whereas the organic flavonol derivatives yield, for the most part, well characterized (and non-toxic) products, the products of the BODIPY CO release reaction are less defined.

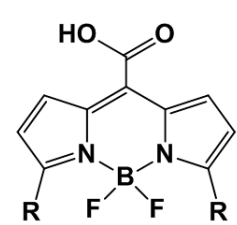

39, $\mathrm{R}=\mathrm{Me}$

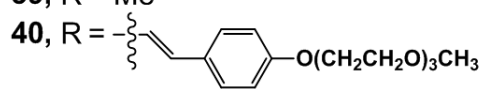

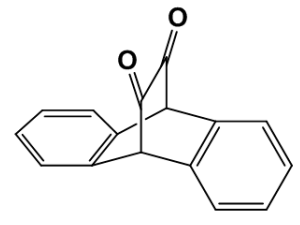

41

Figure 8. Structures of the nonmetallic CORMs 39, 40 (BODIPY derivatives) and 41 (9,10-dihydro9,10-ethanoanthracene-11,12-dione).

Another class of nonmetallic photoCORMs reported by Liao and coworkers allowed a non-invasive and simple approach to track the degree of photo-induced release of $\mathrm{CO}$ via fluorescence measurements [82]. These cyclic diketone compounds (41, Figure 8) require a hydrophobic carrier to be activated, and they were thus incorporated into micelles. In a study showing the first use of this CO releasing composite material for engineered tissue applications, Bashur and coworkers published photoCORM materials incorporated into electrospun scaffolds for engineered vascular tissues [83]. Tissue engineering is a promising approach as bypass graft overcoming coronary heart disease, but has demonstrated poor durability due to aneurysm and thrombosis development. The use of CO for the regulation of the tissue functionalities is thus being investigated [84]. The CO releasing material, 9,10-dihydro-9,10-ethanoanthracene-11,12-dione (41, Figure 8), improves vascular cellular functions in small-diameter grafts by CO liberation. As a photoactivatable and nontoxic CORM, 41 showed CO delivery when incorporated (ca. $2 \% w / w)$ in an electrospun poly-caprolactone scaffold under $470 \mathrm{~nm}$ light irradiation. Photo-activation of $\mathbf{4 1}$ is reproducible under both dry and cell culture conditions. Under dry conditions, 41-derived CO nearly saturates myoglobin in the assay reaching up to $92 \%$ of the theoretical capacity of the CORM-loaded scaffold. Under cell culture conditions, a photo-induction period of $30 \mathrm{~min}$ activation before cellular incubation and fluorescence analysis indicated maximal CO release. CORM 41 does not appear to affect cell viability up to a $100 \mu \mathrm{M}$ concentration, but the cell phenotypic response of rat smooth muscle cells (SMC) does not indicate a significant impact of the $\mathrm{CO}$ delivery. As this could be due to the slow release of $\mathrm{CO}$ during the activation time, a higher CORM-loading could be needed (although an increased dose of CO may also be toxic). This obstacle 
may be surmounted by increasing the hydrophobicity of the environment encapsulating 41, thereby accelerating the activation rate of $\mathrm{CO}$ loss during incubation.

\subsection{PhotoCORM Materials}

An alternative strategy of photoCORM incorporation into material matrices was reported by Schiller and coworkers, via the use of optical device remote-controlled activation of a tetranuclear Mn-based complex (42, Figure 9) embedded on poly-lactide (42a) and polymethacrylate (42b) non-woven fabrics [44]. The same group reported previously an efficient poly-lactide matrix for light-induced $\mathrm{CO}$ delivery from the water-insoluble photoactivatable $\mathrm{Mn}_{2}(\mathrm{CO})_{10} \mathrm{CORM}$ [85]. This matrix-incorporated compound demonstrated antimicrobial activity against Staphylococcus aureus upon light irradiation at $405 \mathrm{~nm}$. Experiments performed on dry compounds (405 nm irradiation) indicated a total amount of $\mathrm{CO}$ being released in the range of $8.1-8.3 \mu \mathrm{mol} / \mathrm{mg}$ of material for $42 \mathrm{a}$ and 11.0-11.7 $\mu \mathrm{mol} / \mathrm{mg}$ for $\mathbf{4 2 b}$ after $30 \mathrm{~min}$ illumination. When the same experiment was performed with an incident radiation of $365 \mathrm{~nm}, 10.7 \mu \mathrm{mol} / \mathrm{mg}$ and $11.5 \mu \mathrm{mol} / \mathrm{mg}$ were measured respectively for $42 \mathrm{a}$ and $\mathbf{4 2 b}$. Surprisingly, the rate of CO delivery of 42a was faster upon irradiation at $405 \mathrm{~nm}$ as compared to $365 \mathrm{~nm}$, which is in contrast with common expectations. The investigation of both structures with the fiber optical device was also reported. Technically, a glass sphere was connected to the extremity of a fiber optic in order to extend the irradiated surface of sample areas, in combination with a laser. $\mathrm{CO}$ release was determined to reach $1.2 \mu \mathrm{mol} / \mathrm{mg}$ after $30 \mathrm{~min}$ at $405 \mathrm{~nm}$ light exposition. This lower value in comparison to dry tests could be explained as a result of a narrower spatial irradiation. In this device, the intensity of the irradiating light plays also a role in $\mathrm{CO}$ release. The concentration of delivered $\mathrm{CO}$ increases with a higher irradiation intensity, at a similar wavelength. 42a was also determined to be nontoxic against 3T3 mouse fibroblast cells, similar to the control polymer matrix.

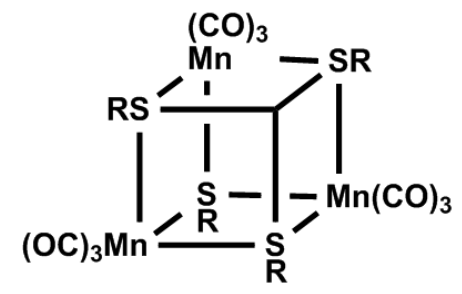

42

Figure 9. Schematic structure of Schiller's tetranuclear photoCORM.

Ueno and coworkers recently published the characterization of engineered protein crystals containing the $\mathrm{Mn}(\mathrm{CO})_{5} \mathrm{Br}$ photoCORM and as a $\mathrm{CO}$ releasing material with the aim of modulating nuclear factor activation [86]. The choice of this particular carrier matrix was driven by the opportunity of using the inner pores of the protein crystals, acting as solvent channels [87,88], and by the natural production of those crystals in insects after infection by a cypovirus. In order to increase the amount of photoCORMs loaded in the carrier, and thus the relative $\mathrm{CO}$ concentration, a mutant of the protein containing a hexa-histidine tag was prepared. This composite protein-CORM matrix showed CO liberation by illumination at $456 \mathrm{~nm}$, while the release was considerably lower without irradiation. Various analyses suggested moreover that $\mathrm{Mn}$ ions are retained into the protein crystal after $\mathrm{CO}$ release, thereby reducing the possible toxicity of $\mathrm{Mn}$ metabolites. Since it is widely known that the intensity and the rate of $\mathrm{CO}$ production into cells are necessary for the activation of the nuclear factor NF- $\mathrm{BB}$ [89], the activity of this NF was checked against the presence of the CORM-embedded protein crystal [90]. The activity of the $\mathrm{kB}$-Fluc transfected HEK293 cells cultured with the photoCORM was evaluated by investigation of the bioluminescence intensity of the cells after $12 \mathrm{~h}$ of incubation. The data indicate that the mutant protein enhanced photoactivation of NF- $\mathrm{KB}$ compared to the wild type protein after $10 \mathrm{~min}$ of light irradiation. There were no notable differences at 0,5 and $20 \mathrm{~min}$ of illumination. The detailed 
mechanism of biological mechanism of this type of composite is currently being investigated by this group. Another strategy to overcome the potential toxicity of the remaining metal-ligand fragment was reported by the group of Smith [91]. This photoCORM system is composed of four and eight manganese cores attached via a dendritic structure (43, Figure 10). The formed dendrimers exhibit stability in the dark and release $\mathrm{CO}$ when irradiated at $410 \mathrm{~nm}$. By contrast, the monomer model system (44, Figure 10) demonstrated a delivery twice as fast in otherwise similar conditions. The total amount of $\mathrm{CO}$ delivered with the eight core dendrimer reached $15 \mathrm{CO}$ eq. The quantum yield and the half-life time were similar for both the four and the eight metallic centers, demonstrating no dependent behavior from one end to another.

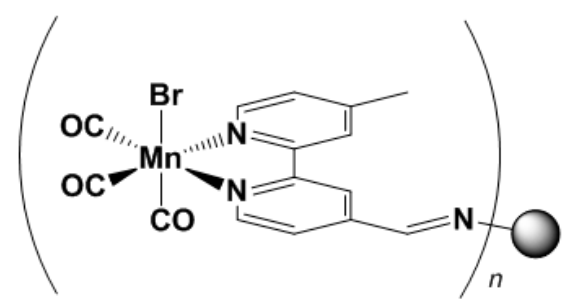

43
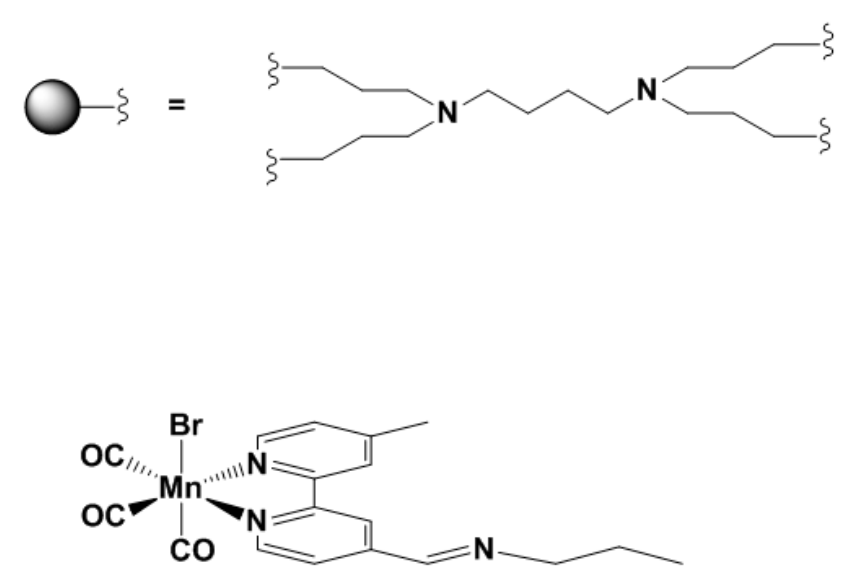

44

Figure 10. Dendritic photoCORM (43) and its monomer model system (44) reported by Smith et al. [91].

\subsection{NIR PhotoCORMs}

Similar to manganese, the $f a c-\left\{\operatorname{Re}(\mathrm{CO})_{3}\right\}^{+}$core was used by Ford and coworkers to synthesize a water-soluble and luminescent photoactivated CORM [92] (45, Figure 11). Specifically, the $-\mathrm{CH}_{2} \mathrm{OH}$ substituents of the phosphinetriyltrimethanol ligand allowed conferring water solubility of the entire complex without modification on the overall charge of the compound. One CO was delivered when irradiated at $405 \mathrm{~nm}$, and the luminescent properties of the photoproduct (following $\mathrm{H}_{2} \mathrm{O}-\mathrm{CO}$ ligand exchange) allowed monitoring cellular uptake of $\mathbf{4 5}$ via confocal fluorescence microscopy. Based on the same ligand, Ford reported in 2015 a water-soluble nanocarrier with upconversion nanoparticles embedded in an amphiphilic polymer containing a water-insoluble Mn-based photoCORM (46, Figure 11) [35]. In such an ensemble, the up-converted nanoparticles absorb NIR light at $980 \mathrm{~nm}$. CO is thus released by ' 45 by reabsorption of the emitted light from the up-converted particles. Previously, Ford and others used NIR wavelengths to uncage lanthanide ion doped with up-converted nanoparticles [93-96]. While the nanoparticles consist of 
$\mathrm{NaGDF}_{4}$ moieties doped with ytterbium and thulium, the amphiliphic matrix is prepared from phospholipid-functionalized poly(ethylene glycol). When 46 is dissolved in $\mathrm{CH}_{2} \mathrm{Cl}_{2}$, it exhibits an MLCT band around $470 \mathrm{~nm}$, thus the $490 \mathrm{~nm}$ light emitted from the particles can excite MLCT transition and thus promote $\mathrm{CO}$ release. In myoglobin experiments, the $\mathrm{CO}$ delivering properties of the composite was assessed. With $365 \mathrm{~nm}$ illumination, $\mathrm{CO}$ is delivered to myoglobin by photo-labilization and migration through the matrix. As expected, a $980 \mathrm{~nm}$ irradiation also induces $\mathrm{CO}$ release via up-converted nanoparticles. Furthermore, the tuning on the polymer capsule could be used to modify the circulation, specificity and elimination of the composite.

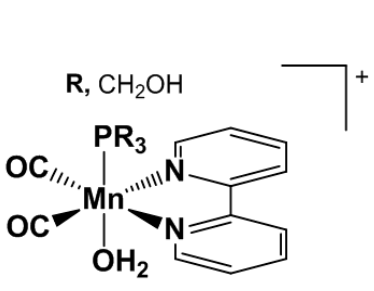

45
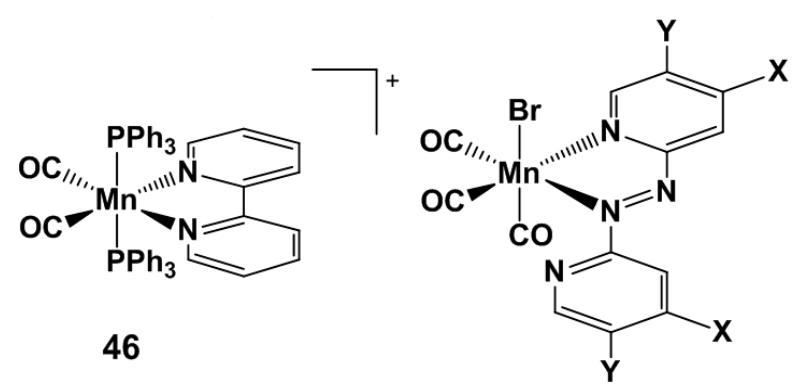

47, $\mathrm{X}=\mathrm{CH}_{3}, \mathrm{Y}=\mathrm{H}$

48, $X=\mathrm{H}, Y=\mathrm{H}$

49, $X=\mathrm{Br}, Y=\mathrm{H}$

50, $\mathrm{X}=\mathrm{CF}_{3}, \mathrm{Y}=\mathrm{H}$

51, $\mathrm{X}=\mathrm{CF}_{3}, \mathrm{Y}=\mathrm{Cl}$

Figure 11. Structure of Ford's bipyridine based photoCORMs (45 and 46) and of Zobi's azobipyridine complexes (47-51).

With the same purpose, Zobi and coworkers described substituted azobipyridine-based photoactivatable CORMs that release CO directly upon NIR irradiation(47-51, Figure 11) [21]. By investigating a series of azobipyridine derivatives, they reported rational fine tuning of the maximal absorbance of the complexes by modification of the $\pi$-frame of the ligand. A similar ligand was previously reported by Mascharak, with a strategy based on two complementary approaches: (a) the stabilization of the LUMO involved in the MLCT transition by increasing the conjugation of aromatic bidentate ligands; (b) the presence of $\sigma$-donor ancillary ligands in order to elevate the energy HOMO-2 orbital (also involved in MLCT) by increasing the electronic density on the metal center [22]. The series of ligands synthesized and characterized by the group of Zobi consists of a symmetric azobipyridine. The introduction of a second pyridine was rationalized so as to lower the energy level of the $\pi^{*} \mathrm{MO}$, given the higher electronegativity of nitrogen compared to carbon. Electron-donating and electron-withdrawing substituents on the $\pi$-frame are expected to finely modulate the MLCT wavelength of absorbance. Electron poor $\pi$-ligands would facilitate the transfer of the electron density from the metal center to the $\pi^{*}$ orbital of the ligand, and thus promote the photo-labilization of the corresponding $\mathrm{CO}$ bond. To confirm these assumptions, the stability of complexes $\mathbf{4 7 - 5 1}$ in $\mathrm{CH}_{2} \mathrm{Cl}_{2}$ was assessed in absence of light, with irradiation at the maximal absorbance wavelength in the visible region (MLCT) of each complex $\left(\lambda_{\max }\right)$, and with NIR light irradiation $(810 \mathrm{~nm})$. The results demonstrated that 47 and 48 are stable in the absence of light for several hours. Conversely, 49-51 exhibit decomposition at room temperature as evidenced by hypochromic shift of the $\lambda_{\max }$. With illumination at $\lambda_{\max }$ all CORMs shows faster decomposition, and as the MLCT band of the complexes tails beyond the visible spectral region, photodecomposition of $\mathbf{5 1}$ is triggered at $810 \mathrm{~nm}$. The myoglobin assay confirmed that the photodegradation is followed by CO release. Similarly, CO release is faster with $\lambda_{\text {max }}$ activation than in the dark. Moreover, DFT calculations confirmed the red-shift of the MLCT absorption band with electron withdrawing substituents (from 625 to $695 \mathrm{~nm}$, for 47 to 51, respectively) observed by the experimental procedure. Although the toxicity of those compounds needs to be investigated, this study represents a major step towards direct NIR photoactivation of metallic CORMs.

\section{Discussion}

In the past ten years, developments in photoCORM chemistry followed two main approaches: (i) the tuning of ligands in the primary coordination sphere of metal-based CORMs to obtain 
a precise wavelength sensitivity in terms of photoactivation, (ii) the use of materials such as matrices, scaffolds, crystals or upconversion particles to either enhance photoCORMs water-solubility, or provide encapsulation of possible toxic metal-based photoproducts. While important steps forwards have been archived in the last decade, the common use of $\mathrm{CO}$ releasing molecule in medical environments is yet to be realized and the key chemical requirements to attain this goal are currently still being mapped. In general, more comprehensive studies regarding the performance of photoCORMs in in vitro and in vivo experiments need to be addressed. Cytotoxicity evaluations of new photoCORMs are not commonly realized while anti-inflammatory assays are rarely reported. In general the biocompatibility of photoCORMs remains a crucial point. This is particularly so with metal-based CORMs, while organic photoCORMs allow for the opportunity of a more straightforward functionalization for the specificity and tunability of their biological properties. In this respect, future investigations on organic photoCORMs are certainly poised to contribute to the next key advances in the field. Furthermore, the appreciation of the new reported photoCORM materials in a complex biological system remains to be evaluated. In addition, one major question is emerging from the NIR activatable photoCORMs: how far can one, or needs one, go to lengthen irradiation wavelengths? As the photoactivation limits are pushed, issues such as thermostability of the photoCORMs become important. It would appear to us that an excitation "limit" will be reached soon. The same perhaps has already been reached. Nevertheless, the large existing panel of tunable photoCORMs will help the scientific community to determine the adequate light sensitivity and will help the researchers to succeed in the transition between the laboratories and the common therapeutic administration.

Acknowledgments: Financial support from the Swiss National Science Foundation (Grant\# PP00P2_144700) is gratefully acknowledged.

Author Contributions: Emmanuel Kottelat searched and selected the literature, and wrote the first draft of the review, whereas Fabio Zobi edited and reviewed the manuscript.

Conflicts of Interest: The authors declare no conflict of interest.

\section{References}

1. Widdop, B. Analysis of Carbon Monoxide. Ann. Clin. Biochem. 2002, 39, 378-391. [CrossRef] [PubMed]

2. Romao, C.C.; Blättler, W.A.; Seixas, J.D.; Bernardes, G.J. Developing Drug Molecules for Therapy with Carbon Monoxide. Chem. Soc. Rev. 2012, 41, 3571-3583. [CrossRef] [PubMed]

3. Fukuto, J.M.; Carrington, S.J.; Tantillo, D.J.; Harrison, J.G.; Ignarro, L.J.; Freeman, B.A.; Chen, A.; Wink, D.A. Small Molecule Signaling Agents: The Integrated Chemistry Biochemistry of Nitrogen Oxides, Oxides of Carbon, Dioxygen, Hydrogen Sulfide, and Their Derived Species. Chem. Res. Toxicol. 2012, 25, 769-793. [CrossRef] [PubMed]

4. Motterlini, R.; Otterbein, L.E. The Therapeutic Potential of Carbon Monoxide. Nat. Rev. Drug. Discov. 2010, 9, 728-743. [CrossRef] [PubMed]

5. Halilovic, A.; Patil, K.A.; Bellner, L.; Marrazzo, G.; Castellano, K.; Cullaro, G.; Dunn, M.W.; Schwartzman, M.L. Knockdown of Heme Oxygenase-2 Impairs Corneal Epithelial Cell Wound Healing. J. Cell. Physiol. 2011, 226, 1732-1740. [CrossRef] [PubMed]

6. Motterlini, R.; Gonzales, A.; Foresti, R.; Clark, J.E.; Green, C.J.; Winslow, R.M. Heme Oxygenase-1-Derived Carbon Monoxide Contributes to the Suppression of Acute Hypertensive Responses in Vivo. Circ. Res. 1998, 83, 568-577. [CrossRef] [PubMed]

7. Otterbein, L.E. Carbon Monoxide: Innovative Anti-Inflammatory Properties of an Age-Old Gas Molecule. Antioxid. Redox Signal. 2002, 4, 309-319. [CrossRef] [PubMed]

8. Nakao, A.; Kaczorowski, D.J.; Sugimoto, R.; Billiar, T.R.; McCurry, K.R. Serial Review Application of Heme Oxygenase-1, Carbon Monoxide and Biliverdin for the Prevention of Intestinal Ischemia/Reperfusion Injury. J. Clin. Biochem. Nutr. 2008, 42, 78-88. [CrossRef] [PubMed]

9. Otterbein, L.E.; Bach, F.H.; Alam, J.; Soares, M.; Lu, H.T.; Wysk, M.; Davis, R.J.; Flavell, R.A.; Choi, A.M. Carbon Monoxide Has Anti-Inflammatory Effects Involving the Mitogen-Activated Protein Kinase Pathway. Nat. Med. 2000, 6, 422-428. [PubMed] 
10. Wu, M.L.; Ho, Y.C.; Yet, S.F. A Central Role of Heme Oxygenase-1 in Cardiovascular Protection. Antioxid. Redox Signal. 2011, 15, 1835-1846. [CrossRef] [PubMed]

11. Neto, J.S.; Nakao, A.; Kimizuka, K.; Romanosky, A.J.; Stolz, D.B.; Uchiyama, T.; Nalesnik, M.A.; Otterbein, L.E.; Murase, N. Protection of Transplant-Induced Renal Ischemia-Reperfusion Injury with Carbon Monoxide. Am. J. Physiol. Renal 2004, 287, F979-F989. [CrossRef] [PubMed]

12. Otterbein, L.E.; Zuckerbraun, B.S.; Haga, M.; Liu, F.; Song, R.; Usheva, A.; Stachulak, C.; Bodyak, N.; Smith, R.N.; Csizmadia, E. Carbon Monoxide Suppresses Arteriosclerotic Lesions Associated with Chronic Graft Rejection and with Balloon Injury. Nat. Med. 2003, 9, 183-190. [CrossRef] [PubMed]

13. Katori, M.; Busuttil, R.W.; Kupiec-Weglinski, J.W. Heme Oxygenase-1 System in Organ Transplantation1. Transplantation 2002, 74, 905-912. [CrossRef] [PubMed]

14. Heinemann, S.H.; Hoshi, T.; Westerhausen, M.; Schiller, A. Carbon Monoxide-Physiology, Detection and Controlled Release. Chem. Commun. 2014, 50, 3644-3660. [CrossRef] [PubMed]

15. Rimmer, R.D.; Pierri, A.E.; Ford, P.C. Photochemically Activated Carbon Monoxide Release for Biological Targets. Toward Developing Air-Stable Photocorms Labilized by Visible Light. Coord. Chem. Rev. 2012, 256, 1509-1519. [CrossRef]

16. Schatzschneider, U. Photocorms: Light-Triggered Release of Carbon Monoxide from the Coordination Sphere of Transition Metal Complexes for Biological Applications. Inorg. Chim. Acta 2011, 374, 19-23. [CrossRef]

17. Schatzschneider, U. Novel Lead Structures Activation Mechanisms for CO-releasing molecules (CORMs). Br. J. Pharmacol. 2015, 172, 1638-1650. [CrossRef] [PubMed]

18. Zobi, F. CO and CO-Releasing Molecules in Medicinal Chemistry. Future Med. Chem. 2013, 5, 175-188. [CrossRef] [PubMed]

19. Motterlini, R.; Clark, J.E.; Foresti, R.; Sarathchandra, P.; Mann, B.E.; Green, C.J. Carbon Monoxide-Releasing Molecules Characterization of Biochemical and Vascular Activities. Circ. Res. 2002, 90, e17-e24. [CrossRef] [PubMed]

20. Hewison, L.; Crook, S.H.; Mann, B.E.; Meijer, A.J.; Adams, H.; Sawle, P.; Motterlini, R.A. New Types of CO-Releasing Molecules (CO-RMs), Based on Iron Dithiocarbamate Complexes and $\left[\mathrm{Fe}(\mathrm{CO})_{3} \mathrm{I}\left(\mathrm{S}_{2} \mathrm{COEt}\right)\right]$. Organometallics 2012, 31, 5823-5834. [CrossRef]

21. Kottelat, E.; Ruggi, A.; Zobi, F. Red-Light Activated Photocorms of Mn(I) Species Bearing Electron Deficient 2,2'-Light Activated. Dalton Trans. 2016, 45, 6920-6927. [CrossRef] [PubMed]

22. Chakraborty, I.; Carrington, S.J.; Mascharak, P.K. Design Strategies to Improve the Sensitivity of Photoactive Metal Carbonyl Complexes (PhotoCORMs) to Visible Light and Their Potential as CO-Donors to Biological Targets. Accounts Chem. Res. 2014, 47, 2603-2611. [CrossRef] [PubMed]

23. Romanski, S.; Kraus, B.; Schatzschneider, U.; Neudörfl, J.M.; Amslinger, S.; Schmalz, H.G. Acyloxybutadiene Iron Tricarbonyl Complexes as Enzyme-Triggered CO-Releasing Molecules (ET-CORMs). Angew. Chem. Int. Ed. 2011, 50, 2392-2396. [CrossRef] [PubMed]

24. Romanski, S.; Rücker, H.; Stamellou, E.; Guttentag, M.; Neudörfl, J.M.; Alberto, R.; Amslinger, S.; Yard, B.; Schmalz, H.G. Iron Dienylphosphate Tricarbonyl Complexes as Water-Soluble Enzyme-Triggered CO-Releasing Molecules (ET-CORMs). Organometallics 2012, 31, 5800-5809. [CrossRef]

25. Romanski, S.; Kraus, B.; Guttentag, M.; Schlundt, W.; Rücker, H.; Adler, A.; Neudörfl, J.M.; Alberto, R.; Amslinger, S.; Schmalz, H.G. Acyloxybutadiene Tricarbonyl Iron Complexes as Enzyme-Triggered CO-Releasing Molecules (ET-CORMs): A Structure-Activity Relationship Study. Dalton Trans. 2012, 41, 13862-13875. [CrossRef] [PubMed]

26. Botov, S.; Stamellou, E.; Romanski, S.; Guttentag, M.; Alberto, R.; Neudörfl, J M.; Yard, B.; Schmalz, H.G. Synthesis and Performance of Acyloxy-Diene-Fe $(\mathrm{CO})_{3}$ Complexes with Variable Chain Lengths as Enzyme-Triggered Carbon Monoxide-Releasing Molecules. Organometallics 2013, 32, 3587-3594. [CrossRef]

27. Kunz, P.C.; Meyer, H.; Barthel, J.; Sollazzo, S.; Schmidt, A.M.; Janiak, C. Metal Carbonyls Supported on Iron Oxide Nanoparticles to Trigger the CO-Gasotransmitter Release by Magnetic Heating. Chem. Commun. 2013, 49, 4896-4898. [CrossRef] [PubMed]

28. Gonzales, M.A.; Mascharak, P.K. Photoactive Metal Carbonyl Complexes as Potential Agents for Targeted CO Delivery. J. Inorg. Biochem. 2014, 133, 127-135. [CrossRef] [PubMed]

29. Wright, M.A.; Wright, J.A. PhotoCORMs: CO Release Moves into the Visible. Dalton Trans. 2016, 45, 6801-6811. [CrossRef] [PubMed] 
30. Dördelmann, G.; Pfeiffer, H.; Birkner, A.; Schatzschneider, U. Silicium Dioxide Nanoparticles as Carriers for Photoactivatable CO-Releasing Molecules (PhotoCORMs). Inorg. Chem. 2011, 50, 4362-4367. [CrossRef] [PubMed]

31. Niesel, J.; Pinto, A.; NDongo, H.W.P.; Merz, K.; Ott, I.; Gust, R.; Schatzschneider, U. Photoinduced CO Release, Cellular Uptake and Cytotoxicity of a Tris(Pyrazolyl)Methane (tpm) Manganese Tricarbonyl Complex. Chem. Commun. 2008, 1798-1800. [CrossRef] [PubMed]

32. Rudolf, P.; Kanal, F.; Knorr, J.; Nagel, C.; Niesel, J.; Brixner, T.; Schatzschneider, U.; Nuernberger, P. Ultrafast Photochemistry of a Manganese-Tricarbonyl CO-Releasing Molecule (CORM) in Aqueous Solution. J. Phys. Chem. Lett. 2013, 4, 596-602. [CrossRef] [PubMed]

33. Pfeiffer, H.; Rojas, A.; Niesel, J.; Schatzschneider, U. Sonogashira "Click" Reactions for the N-Terminal and Side-Chain Functionalization of Peptides with $\left[\mathrm{Mn}(\mathrm{CO})_{3}(\mathrm{tpm})\right]^{+}$-Based CO Releasing Molecules (tpm = Tris(Pyrazolyl)Methane). Dalton Trans. 2009, 4292-4298. [CrossRef] [PubMed]

34. Meister, K.; Niesel, J.; Schatzschneider, U.; Metzler-Nolte, N.; Schmidt, D.A.; Havenith, M. Label-Free Imaging of Metal-Carbonyl Complexes in Live Cells by Raman Microspectroscopy. Angew. Chem. Int. Ed. 2010, 49, 3310-3312. [CrossRef] [PubMed]

35. Pierri, A.E.; Huang, P.J.; Garcia, J.V.; Stanfill, J.G.; Chui, M.; Wu, G.; Zheng, N.; Ford, P.C. A PhotoCORM Nanocarrier for CO Release Using NIR Light. Chem. Commun. 2015, 51, 2072-2075. [CrossRef] [PubMed]

36. Crespy, D.; Landfester, K.; Schubert, U.S.; Schiller, A. Potential Photoactivated Metallopharmaceuticals: From Active Molecules to Supported Drugs. Chem. Commun. 2010, 46, 6651-6662. [CrossRef] [PubMed]

37. García-Gallego, S.; Bernardes, G. Carbon-Monoxide-Releasing Molecules for the Delivery of Therapeutic CO In Vivo. Angew. Chem. Int. Ed. 2014, 53, 9712-9721. [CrossRef] [PubMed]

38. Mann, B.E. Carbon monoxide: An essential signalling molecule. In Medicinal Organometallic Chemistry; Gerard, J., Metzler-Note, N., Eds.; Springer: New York, NY, USA, 2010; Volume 32, pp. 247-285.

39. Marhenke, J.; Trevino, K.; Works, C. The Chemistry, Biology and Design of Photochemical CO Releasing Molecules and the Efforts to Detect CO for Biological Applications. Coord. Chem. Rev. 2016, 306, 533-543. [CrossRef]

40. Ji, X.; Damera, K.; Zheng, Y.; Yu, B.; Otterbein, L.E.; Wang, B. Toward Carbon Monoxide-Based Therapeutics: Critical Drug Delivery and Developability Issues. J. Pharm. Sci. 2016, 105, 406-416. [CrossRef] [PubMed]

41. Rimmer, R.D.; Richter, H.; Ford, P.C. A Photochemical Precursor for Carbon Monoxide Release in Aerated Aqueous Media. Inorg. Chem. 2009, 49, 1180-1185. [CrossRef] [PubMed]

42. Zobi, F.; Degonda, A.; Schaub, M.C.; Bogdanova, A.Y. CO Releasing Properties and Cytoprotective Effect of cis-trans-[ReII $\left.(\mathrm{CO})_{2} \mathrm{Br}_{2} \mathrm{~L}_{2}\right]_{n}$ Complexes. Inorg. Chem. 2010, 49, 7313-7322. [CrossRef] [PubMed]

43. McLean, S.; Mann, B.E.; Poole, R.K. Sulfite Species Enhance Carbon Monoxide Release from CO-Releasing Molecules: Implications for the Deoxymyoglobin Assay of Activity. Anal. Biochem. 2012, 427, $36-40$. [CrossRef] [PubMed]

44. Gläser, S.; Mede, R.; Görls, H.; Seupel, S.; Bohlender, C.; Wyrwa, R.; Schirmer, S.; Dochow, S.; Reddy, G.U.; Popp, J. Remote-Controlled Delivery of CO Via Photoactive CO-Releasing Materials on a Fiber Optical Device. Dalton Trans. 2016, 45, 13222-13233. [CrossRef] [PubMed]

45. Klein, M.; Neugebauer, U.; Gheisari, A.; Malassa, A.; Jazzazi, T.M.; Froehlich, F.; Westerhausen, M.; Schmitt, M.; Popp, J.R. IR Spectroscopic Methods for the Investigation of the CO Release from CORMs. J. Phys. Chem. A 2014, 118, 5381-5390. [CrossRef] [PubMed]

46. Michel, B.W.; Lippert, A.R.; Chang, C.J. A Reaction-Based Fluorescent Probe for Selective Imaging of Carbon Monoxide in Living Cells Using a Palladium-Mediated Carbonylation. J. Am. Chem. Soc. 2012, 134, 15668-15671. [CrossRef] [PubMed]

47. Chapman, O.; Wojtkowski, P.; Adam, W.; Rodriguez, O.; Rucktäschel, R. Photochemical transformations. XLIV. Cyclic peroxides. Synthesis and chemistry of.alpha.-lactones. J. Am. Chem. Soc. 1972, 94, 1365-1367. [CrossRef]

48. Kuzmanich, G.; Garcia, P.; Adam, W.; Rodriguez, O.; Rucktäschel, R. Ring strain release as a strategy to enable the singlet state photodecarbonylation of crystalline 1,4-cyclobutanediones. J. Phys. Org. Chem. 2011, 24, 883-888. [CrossRef]

49. Poloukhtine, A.; Popik, V.V. Mechanism of the Cyclopropenone Decarbonylation Reaction.A Density Functional Theory and Transient Spectroscopy Study. J. Phys. Chem. A 2006, 110, 1749-1757. [CrossRef] [PubMed] 
50. Poloukhtine, A.; Popik, V.V. Highly Efficient Photochemical Generation of a Triple Bond: Synthesis, Properties, and Photodecarbonylation of Cyclopropenones. J. Org. Chem. 2003, 68, 7833-7840. [CrossRef] [PubMed]

51. Poloukhtine, A.A.; Mbua, N.E.; Wolfert, M.A.; Boons, G.J.; Popik, V.V. Selective Labeling of Living Cells by a Photo-Triggered Click Reaction. J. Am. Chem. Soc. 2009, 131, 15769-15776. [CrossRef] [PubMed]

52. Kuzmanich, G.; Gard, M.N.; Garcia-Garibay, M.A. Photonic Amplification by a Singlet-State Quantum Chain Reaction in the Photodecarbonylation of Crystalline Diarylcyclopropenones. J. Am. Chem. Soc. 2009, 131, 11606-11614. [CrossRef] [PubMed]

53. Berends, H.M.; Kurz, P. Investigation of Light-Triggered Carbon Monoxide Release from Two Manganese PhotoCORMs by IR, UV-vis EPR Spectroscopy. Inorg. Chim. Acta 2012, 380, 141-147. [CrossRef]

54. Üstün, E.; Ayvaz, M.Ç.; Çelebi, M.S.; Aşcı, G.; Demir, S.; Özdemir, İ. Structure, CO-Releasing Property, Electrochemistry, DFT Calculation, and Antioxidant Activity of Benzimidazole Derivative Substituted $\left[\mathrm{Mn}(\mathrm{CO})_{3}(\mathrm{bpy}) \mathrm{L}\right] \mathrm{PF}_{6}$ Type Novel Manganese Complexes. Inorg. Chim. Acta 2016, 450, 182-189. [CrossRef]

55. Üstün, E.; Özgür, A.; Coşkun, K.A.; Demir, S.; Özdemir, İ; Tutar, Y. CO-Releasing Properties and Anticancer Activities of Manganese Complexes with Imidazole/Benzimidazole Ligands. J. Coord. Chem. 2016, 69, 3384-3394.

56. Tinajero-Trejo, M.; Rana, N.; Nagel, C.; Jesse, H.E.; Smith, T.W.; Wareham, L.K.; Hippler, M.; Schatzschneider, U.; Poole, R.K. Antimicrobial Activity of the Manganese Photoactivated Carbon Monoxide-Releasing Molecule $\left[\mathrm{Mn}(\mathrm{CO})_{3}\left(\mathrm{tpa}_{-} \mathrm{k}^{3} \mathrm{~N}\right)\right]^{+}$against a Pathogenic Escherichia coli That Causes Urinary Infections. Antioxid. Redox Signal. 2016, 24, 765-780. [CrossRef] [PubMed]

57. Yang, S.; Chen, M.; Zhou, L.; Zhang, G.; Gao, Z.; Zhang, W. Photo-Activated Co-Releasing Molecules (Photocorms) of Robust Sawhorse Scaffolds $\left[\mu^{2}-\mathrm{OOCR}^{1}, \eta^{1}-\mathrm{NH}_{2} \mathrm{CHR}^{2}(\mathrm{C}=\mathrm{O}] \mathrm{OCH}_{3}, \mathrm{Ru}(\mathrm{I})_{2} \mathrm{CO}_{4}\right.$. Dalton Trans. 2016, 45, 3727-3733. [CrossRef] [PubMed]

58. Carrington, S.J.; Chakraborty, I.; Bernard, J.M.; Mascharak, P.K. A Theranostic Two-Tone Luminescent Photocorm Derived from Re (I) and (2-Pyridyl)-Benzothiazole: Trackable CO Delivery to Malignant Cells. Inorg. Chem. 2016, 55, 7852-7858. [CrossRef] [PubMed]

59. Kretschmer, R.; Gessner, G.; Görls, H.; Heinemann, S.H.; Westerhausen, M. Dicarbonyl-Bis(Cysteamine) Iron (II): A Light Induced Carbon Monoxide Releasing Molecule Based on Iron (CORM-S1). J. Inorg. Biochem. 2011, 105, 6-9. [CrossRef] [PubMed]

60. Hewison, L.; Johnson, T.R.; Mann, B.E.; Meijer, A.J.; Sawle, P.; Motterlini, R. A Re-Investigation of $\left[\mathrm{Fe}(\mathrm{L}-\mathrm{Cysteinate})_{2}(\mathrm{CO})_{2}\right]^{2-}$ : An Example of Non-Heme CO Coordination of Possible Relevance to CO Binding to Ion Channel Receptors. Dalton Trans. 2011, 40, 8328-8334. [CrossRef] [PubMed]

61. Mede, R.; Klein, M.; Claus, R.A.; Krieck, S.; Quickert, S.; Görls, H.; Neugebauer, U.; Schmitt, M.; Gessner, G.; Heinemann, S.H. CORM-EDE1: A Highly Water-Soluble and Nontoxic Manganese-Based PhotoCORM with a Biogenic Ligand Sphere. Inorg. Chem. 2015, 55, 104-113. [CrossRef] [PubMed]

62. Poh, H.T.; Sim, B.T.; Chwee, T.S.; Leong, W.K.; and Fan, W.Y. The Dithiolate-Bridged Diiron Hexacarbonyl Complex $\mathrm{Na}_{2}\left[\left(\mathrm{M}-\mathrm{SCH}_{2} \mathrm{CH}_{2} \mathrm{COO}\right) \mathrm{Fe}(\mathrm{CO})_{3}\right]_{2}$ as a Water-Soluble PhotoCORM. Organometallics 2014, 33, 959-963. [CrossRef]

63. Gonzalez, M.A.; Yim, M.A.; Cheng, S.; Moyes, A.; Hobbs, A.J.; Mascharak, P.K. Manganese Carbonyls Bearing Tripodal Polypyridine Ligands as Photoactive Carbon Monoxide-Releasing Molecules. Inorg. Chem. 2011, 51, 601-608. [CrossRef] [PubMed]

64. Gonzalez, M.A.; Carrington, S.J.; Fry, N.L.; Martinez, J.L.; Mascharak, P.K. Syntheses, Structures, and Properties of New Manganese Carbonyls as Photoactive CO-Releasing Molecules: Design Strategies That Lead to CO Photolability in the Visible Region. Inorg. Chem. 2012, 51, 11930-11940. [CrossRef] [PubMed]

65. Chakraborty, I.; Carrington, S.J.; Mascharak, P.K. Photodelivery of CO by Designed Photocorms: Correlation between Absorption in the Visible Region and Metal-CO Bond Labilization in Carbonyl Complexes. ChemMedChem 2014, 9, 1266-1274. [CrossRef] [PubMed]

66. Vlček, A., Jr.; Farrell, I.R.; Liard, D.J.; Matousek, P.; Towrie, M.; Parker, A.W.; Grills, D.C.; George, M.W. Early Photochemical Dynamics of Organometallic Compounds Studied by Ultrafast Time-Resolved Spectroscopic Techniques. Dalton Trans. 2002, 701-712.

67. Jimenez, J.; Chakraborty, I.; Carrington, S.J.; Mascharak, P.K. Light-Triggered CO Delivery by a Water-Soluble and Biocompatible Manganese PhotoCORM. Dalton Trans. 2016, 45, 13204-13213. [CrossRef] [PubMed] 
68. Jimenez, J.; Chakraborty, I.; Mascharak, P.K. Synthesis and Assessment of Coered Cls, D.C.; George, M.W.; Early Photochemical Dynamics of $\alpha$-imenez, J.; Chakof Varied Complexity. Eur. J. Inorg. Chem. 2015, 2015, 5021-5026. [CrossRef] [PubMed]

69. Santoro, G.; Beltrami, R.; Kottelat, E.; Blacque, O.; Bogdanova, A.Y.; Zobi, F. N-Nitrosamine- $\left.\{\text { cis-Re[COC }]_{2}\right\}^{2+}$ Cobalamin Conjugates as Mixed Co/No-Releasing Molecules. Dalton Trans. 2016, 45, 1504-1513. [CrossRef] [PubMed]

70. Blanářová, O.V.; Jelínková, I.; Szöőr, Á.; Skender, B.; Souček, K.; Horváth, V.; Vaculová, A.; Sova, P.; Szöllősi, J. Cisplatin and a Potent Platinum (IV) Complex-Mediated Enhancement of Trail-Induced Cancer Cells Killing Is Associated with Modulation of Upstream Events in the Extrinsic Apoptotic Pathway. Carcinogenesis 2011, 32, 42-51. [CrossRef] [PubMed]

71. Horváth, V.; Blanářová, O.; Švihálková-Šindlerová, L.; Souček, K.; Hofmanová, J.; Sova, P.; Kroutil, A.; Fedoročko, P.; Kozubík, A. Platinum (IV) Complex with Adamantylamine Overcomes Intrinsic Resistance to Cisplatin in Ovarian Cancer Cells. Gynecol. Oncol. 2006, 102, 32-40. [CrossRef] [PubMed]

72. Yempally, V.; Kyran, S.J.; Raju, R.K.; Fan, W.Y.; Brothers, E.N.; Darensbourg, D.J.; Bengali, A.A. Thermal and Photochemical Reactivity of Manganese Tricarbonyl and Tetracarbonyl Complexes with a Bulky Diazabutadiene Ligand. Inorg. Chem. 2014, 53, 4081-4088. [CrossRef] [PubMed]

73. Mansour, A.M.; Shehab, O.R. Experimental and Quantum Chemical Calculations of Novel Photoactivatable Manganese (I) Tricarbonyl Complexes. J. Organomet. Chem. 2016, 822, 91-99. [CrossRef]

74. Mansour, A.M. Crystal Structure, DFT, Spectroscopic and Biological Activity Evaluation of Analgin Complexes with Co (II), Ni (II) and Cu (II). Dalton Trans. 2014, 43, 15950-15957. [CrossRef] [PubMed]

75. Mansour, A.M. Tazarotene Copper Complexes: Synthesis, Crystal Structure, DFT and Biological Activity Evaluation. Polyhedron 2016, 109, 99-106. [CrossRef]

76. Anderson, S.N.; Larson, M.T.; Berreau, L.M. Solution or Solid-It Doesn't Matter: Visible Light-Induced CO Release Reactivity of Zinc Flavonolato Complexes. Dalton Trans. 2016, 45, 14570-14580. [CrossRef] [PubMed]

77. Anderson, S.N.; Richards, J.M.; Esquer, H.J.; Benninghoff, A.D.; Arif, A.M.; Berreau, L.M. A Structurally-Tunable 3-Hydroxyflavone Motif for Visible Light-Induced Carbon Monoxide-Releasing Molecules (CORMs). ChemistryOpen 2015, 4, 590-594. [CrossRef] [PubMed]

78. Wang, D.; Viennois, E.; Ji, K.; Damera, K.; Draganov, A.; Zheng, Y.; Dai, C.; Merlin, D.; Wang, B. A Click-and-Release Approach to CO Prodrugs. Chem. Commun. 2014, 50, 15890-15893. [CrossRef] [PubMed]

79. Palao Utiel, E.; Slanina, T.; Muchova, L.; Šolomek, T.; Vitek, L.; Klán, P. Transition-Metal-Free CO-Releasing Bodipy Derivatives Activatable by Visible to NIR Light as Promising Bioactive Molecules. J. Am. Chem. Soc. 2016, 126-133. [CrossRef] [PubMed]

80. Pap, J.S.; Kaizer, J.; Speier, G. Model Systems for the CO-Releasing Flavonol 2,4-Dioxygenase Enzyme. Coord. Chem. Rev. 2010, 254, 781-793. [CrossRef]

81. Fetzner, S. Ring-Cleaving Dioxygenases with a Cupin Fold. Appl. Environ. Microbiol. 2012, 78, $2505-2514$. [CrossRef] [PubMed]

82. Peng, P.; Wang, C.; Shi, Z.; Johns, V.K.; Ma, L.; Oyer, J.; Copik, A.; Igarashi, R.; Liao, Y. Visible-Light Activatable Organic CO-Releasing Molecules (PhotoCORMs) That Simultaneously Generate Fluorophores. Org. Biomol. Chem. 2013, 11, 6671-6674. [CrossRef] [PubMed]

83. Michael, E.; Abeyrathna, N.; Patel, A.V.; Liao, Y.; Bashur, C.A. Incorporation of Photo-Carbon Monoxide Releasing Materials into Electrospun Scaffolds for Vascular Tissue Engineering. Biomed. Mater. 2016, 11, 025009. [CrossRef] [PubMed]

84. Bauer, I.; Pannen, B.H. Bench-to-Bedside Review: Carbon Monoxide-from Mitochondrial Poisoning to Therapeutic Use. Crit. Care 2009, 13, 1. [CrossRef] [PubMed]

85. Bohlender, C.; Gläser, S.; Klein, M.; Weisser, J.; Thein, S.; Neugebauer, U.; Popp, J.; Wyrwa, R.; Schiller, A. Light-Triggered CO Release from Nanoporous Non-Wovens. J. Mater. Chem. B 2014, 2, 1454-1463. [CrossRef]

86. Tabe, H.; Shimoi, T.; Boudes, M.; Abe, S.; Coulibaly, F.; Kitagawa, S.; Mori, H.; Ueno, T. Photoactivatable CO Release from Engineered Protein Crystals to Modulate NF-кB Activation. Chem. Commun. 2016, 52, 4545-4548. [CrossRef] [PubMed]

87. Tabe, H.; Fujita, K.; Abe, S.; Tsujimoto, M.; Kuchimaru, T.; Kizaka-Kondoh, S.; Takano, M.; Kitagawa, S.; Ueno, T. Preparation of a Cross-Linked Porous Protein Crystal Containing Ru Carbonyl Complexes as a CO-Releasing Extracellular Scaffold. Inorg. Chem. 2014, 54, 215-220. [CrossRef] [PubMed] 
88. Tabe, H.; Shimoi, T.; Fujita, K.; Abe, S.; Ijiri, H.; Tsujimoto, M.; Kuchimaru, T.; Kizaka-Kondo, S.; Mori, H.; Kitagawa, S. Design of a CO-Releasing Extracellular Scaffold Using in Vivo Protein Crystals. Chem. Lett. 2015, 44, 342-344. [CrossRef]

89. Chlopicki, S.; Lomnicka, M.; Fedorowicz, A.; Grochal, E.; Kramkowski, K.; Mogielnicki, A.; Buczko, W.; Motterlini, R. Inhibition of Platelet Aggregation by Carbon Monoxide-Releasing Molecules (CO-RMs): Comparison with NO Donors. Naunyn Schmiedebergs Arch. Pharmacol. 2012, 385, 641-650. [CrossRef] [PubMed]

90. Brasier, A.; Tate, J.; Habener, J. Optimized Use of the Firefly Luciferase Assay as a Reporter Gene in Mammalian Cell Lines. Biotechniques 1988, 7, 1116-1122.

91. Govender, P.; Pai, S.; Schatzschneider, U.; Smith, G.S. Next Generation PhotoCORMs: Polynuclear Tricarbonylmanganese (I)-Functionalized Polypyridyl Metallodendrimers. Inorg. Chem. 2013, 52, 5470-5478. [CrossRef] [PubMed]

92. Pierri, A.E.; Pallaoro, A.; Wu, G.; Ford, P.C. A Luminescent Biocompatible PhotoCORM. J. Am. Chem. Soc. 2012, 134, 18197-18200. [CrossRef] [PubMed]

93. Carling, C.J.; Nourmohammadian, F.; Boyer, J.C.; Branda, N.R. Remote-Control Photorelease of Caged Compounds Using Near-Infrared Light and Upconverting Nanoparticles. Angew. Chem. Int. Ed. 2010, 122, 3870-3873. [CrossRef]

94. Zheng, Q.; Bonoiu, A.; Ohulchanskyy, T.Y.; He, G.S.; Prasad, P.N. Water-Soluble Two-Photon Absorbing Nitrosyl Complex for Light-Activated Therapy through Nitric Oxide Release. Mol. Pharm. 2008, 5, 389-398. [CrossRef] [PubMed]

95. Garcia, J.V.; Yang, J.; Shen, D.; Yao, C.; Li, X.; Wang, R.; Stucky, G.D.; Zhao, D.; Ford, P.C.; Zhang, F. Nanostructured Materials. Small 2012, 8, 3800-3805. [CrossRef] [PubMed]

96. Wecksler, S.; Mikhailovsky, A.; Ford, P.C. Photochemical Production of Nitric Oxide Via Two-Photon Excitation with NIR Light. J. Am. Chem. Soc. 2004, 126, 13566-13567. [CrossRef] [PubMed]

(C) 2017 by the authors. Licensee MDPI, Basel, Switzerland. This article is an open access article distributed under the terms and conditions of the Creative Commons Attribution (CC BY) license (http:/ / creativecommons.org/licenses/by/4.0/). 